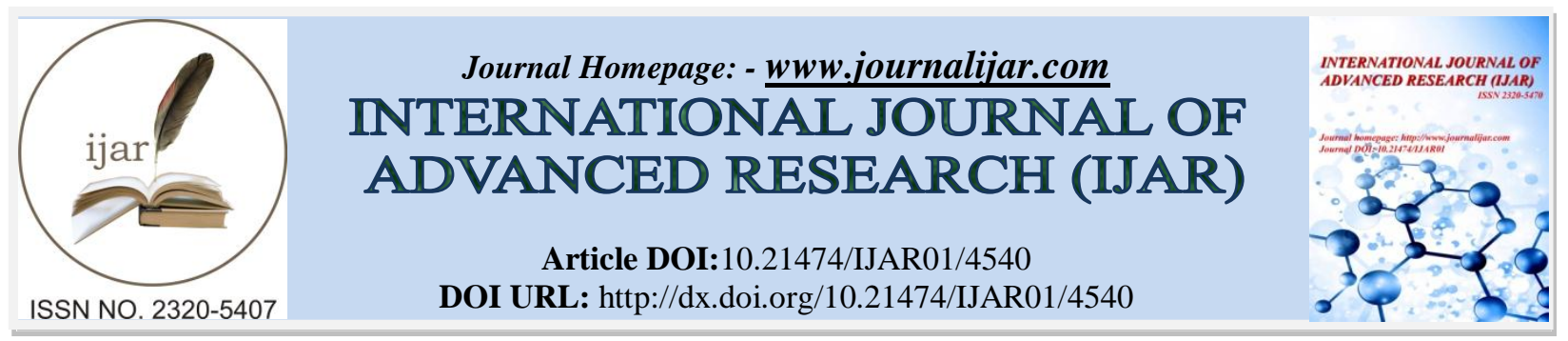

RESEARCH ARTICLE

\title{
DIVERSIFIED FARMING OF SUGARCANE AND PULSES: AN ACCESS TOWARDS MAINTAINING YAWNING PRODUCTIVITY GAPS AND SECURE FOOD FOR INDIA.
}

\section{"Dr. Shriprakash Yadav ${ }^{1}$ and Smt.Sonia Yadav ${ }^{2}$.}

1. Scientific officer (Agro), Sugarcane Research Institute,U.P. Council of Sugarcane Research, Lodhipur Shahjahanpur U.P, 242001.

2. Scientific officer (Seed),Sugarcane Research Institute,U.P. Council of Sugarcane Research, Lodhipur Shahjahanpur U.P, 242001.

\section{Manuscript Info}

\section{Manuscript History}

Received: 19 April 2017

Final Accepted: 21 May 2017

Published: June 2017

Key words:-

Intercropping, Diversified farming,

Sugarcane, Crop residue recycling,

Productivity, Secure food.

\section{Abstract}

There has been a wrong notions that pulse crops are meant for the poor and marginal lands. But scientists have demonstrated that with the available technology adoption, the yield of pulses as well as sugarcane could be considerably increased depending on the situation, varieties and improved technologies. Pulses have very good opportunity to find place in different agro-ecosystems. Now-days, soil organic carbon and crop productivity have become major concern in sustainable agriculture. From 1980 to 2016, the total cropped area of pulses in India increased from 22.46 to $26.40 \mathrm{M}$ ha. Due to stagnate in production and an increase in population, the per capita availability of pulses and sugar have been declined during 2009-2015.In 2016 production of pulses and also sugar have increased providing pulse $47.23 \mathrm{~g} / \mathrm{capita} /$ day and sugar $23 \mathrm{~kg}$ per capita annually. Significant enhancement in area and productivity of pulse is possible by growing as intercrop with sugarcane crop which is grown in more than 5.15 million ha area in the country. Thus there is a great scope of increasing area under pulse through crop diversification /intensification .Adoption of pulse crops with autumn (October) planted cane in furrow-irrigated raised bed system with $90 \mathrm{~cm}$ row spacing of sugarcane planted in furrow/trenches and component crop is on raised beds/spaces between two trenches. This approach also provides great scope for increasing crop yield and optimizing input use efficiencies in the system. Crop residues recycling of pulses addresses the key issue of decreasing soil organic carbon created due to indiscriminate use of fertilizers and lower use of organic manures. Mechanization of diversified cropping system will certainly boost the adoption of recommended technologies by the farmers, Thus cost of production could be reduced and profitability may be increased with introducing these crops in irrigated agro-ecosystem with improving soil fertility and food security in sustainable way for longer period. 


\section{Introduction:-}

The Indian agriculture as a whole is undergoing several transformative changes. Growing population changing lifestyle, expending urbanization and accelerating climate changes are creating new challenges on national agricultural research and development .Green revolution led to quantum jump in food chain production from 51 million tonns in 2013-14.The area under rice and wheat which was 36.94 and 14.99 million ha in 1967-1968 gone upto 43.9 and 14.99 million ha in 2013-2014, respectively.

By virtue of their adverse nature with respect to duration, adoption to different climate and other nitrogen associated benefits pulses are the integral part of the different cropping systems of the country. Their versatile nature makes them ideal components in crop diversification and intensification. Pulses contain 22-24\% protein which is about 2-3 times more than the wheat and rice, respectively. The major pulse crops grown in India are chick pea, mung bean, urd bean, lentil, pea and lathyrus (Singh, 2015).

India is the largest producer and consumer of the pulses in the world. India contributes about $24 \%$ of the total pulses production globally. The main pulse producing states are Madhya Pradesh, Rajasthan, Maharashtra, Uttar Pradesh, Karnataka and Andhra Pradesh with an average area of 20.13, 16.40, 13.80, 9.5, 9.3 and 7.9\%, respectively to the total pulses area of the country. Among the pulses, chickpea contributes major share in the pulse basket of the country with about $48 \%$ followed by pigeon pea (15\%), mung bean and urd bean (7\% each), lentil and field pea $5 \%$ each.

The value of pulses as intercrop in sugarcane could be recognized from the fact that they supplement nitrogen, suppress weeds, improve soil properties and sustain plant ratoon system. Garside and Bell (1999) concluded that well managed legume crops are best adopted to play an important role in sugarcane based cropping systems. Intercropping of pulses in sugarcane add substantial quantity of nitrogen through mineralization after incorporation of the stalks of intercrops (Prakash and Hunsingi, 1994). Moreover, intercropping of winter pulses is tool to promote autumn planting of sugarcane giving 15-20\% higher cane yield and 0.5 units more sugar recovery than spring planted cane. On the other hand, intercropping of mungbean / cowpea in spring planted cane can bring an additional one million hectare area under pulses in northern states with their increased productivity because of high yielding irrigated environment.

Table1:- Growing population and estimated sugar consumption in India

\begin{tabular}{|c|c|c|c|c|}
\hline Year & \multicolumn{2}{|c|}{ Population in millions } & \multicolumn{2}{c|}{ Sugar consumption (m tonnes) } \\
\hline & & @ 20kg per capita & @ 30kg per capita & @ 40kg per capita \\
\hline 2010 & 1180 & 23.60 & 35.40 & 47.20 \\
\hline 2030 & 1470 & 29.40 & 44.10 & 58.82 \\
\hline 2050 & 1757 & 35.10 & 52.71 & 70.28 \\
\hline
\end{tabular}

\section{Sugarcane Scenario in the world:-}

Sugarcane was considered as rare commodity and it was used as medicine rather than as sweetener. Globally it is an integral part of food to provide energy. Carbohydrates such as starch, sugar and polysaccharides are essential components in the human diet (Blume, 1985). Sugar is today regarded as a mass consumption item and is also accounts for a large share of the total calorie intake of an average household (Pruthi, 1995). Worldwide per capita sugar consumption reached the equivalent of an energy intake of more than $837 \mathrm{kj}$ (kcl.) daily (Hagelberg and Harris, 1976). Presently, the sugarcane crop provides the third highest quantity of human consumed plant calorie (152 Kcl/capita/day) following rice $(533 \mathrm{Kcl}$.) and wheat $(530 \mathrm{Kcl}$.) as reported by Moore et.al. (2014). Consumption of sugar has increased remarkably, faster than the growth of the world's population. Presently, it has gone up to 171 million tonnes (2015) and annual per capita consumption has risen to the level of $23 \mathrm{~kg} / \mathrm{year}$ (2015). India is second largest producer of sugarcane (18.18\%) and sugar (15.81\%) next to Brazil. Out of 101 sugarcane producing countries, top ten countries contribute $81.47 \%$ in area and $82.85 \%$ in production of world. Top ten cane yield (t/ha) producing countries are Peru (133.72), Ethiopia (119.57), Egypt (115.33), Senegal (114.10), Malawi (107.41), Zambia (102.56), Burkina Faso (102.13), Guatemala (100.69) and United Republic of Tanzania (100.00) and Nicaragua (98.18) but these countries contribute only $2.59 \%$ in area and $3.97 \%$ in production of the world total of sugarcane. 
Table 2:-Top five countries in sugarcane area, production and yield (2016).

\begin{tabular}{|l|l|l|l|l|l|l|}
\hline \multirow{2}{*}{ Rank } & Area wise & Production wise & Yield wise \\
\cline { 2 - 7 } & Country & Area (mha) & Country & Production(mt) & Country & Yield (t/ha) \\
\hline 1 & Brazil & 10.44 & Brazil & 737.16 & Peru & 133.72 \\
\hline 2 & India & 5.10 & India & 362.33 & Ethiopia & 119.57 \\
\hline 3 & China & 1.75 & China & 126.00 & Egypt & 115.33 \\
\hline 4 & Thailand & 1.35 & Thailand & 104.00 & Senegal & 114.10 \\
\hline 5 & Pakistan & 1.17 & Pakistan & 67.46 & Malawi & 107.41 \\
\hline \multicolumn{7}{|l|}{} \\
\hline
\end{tabular}

\section{Sugarcane Scenario in India:-}

There are two distinct zones for sugarcane cultivation in India: Tropical and subtropical. Subtropical north zone while comprising $56 \%$ area contributes only $47 \%$ to total cane production at the national level. The lower cane productivity $(62.26 \mathrm{t} / \mathrm{ha})$ in the subtropical zone as compared to tropical zone $(81.75 \mathrm{t} / \mathrm{ha})$ is caused by imbalances in area sand production between the two zones.

In 65 years, from 1950, if we take the lowest and highest values in area, production and yield then the picture will be clear. In area, lowest (1.41 mha) and highest (5.15 mha) were recorded in 1953-54 and 2006-07 years respectively. In other words, area increased nearly by four fold.

Table 3:- Lowest and highest values (years) for area, production and yield India since, 1950

\begin{tabular}{|c|c|c|c|c|}
\hline Particulars & \multicolumn{2}{|c|}{ Lowest } & \multicolumn{2}{c|}{ Highest } \\
\hline & Year & Value & Year & 5.15 \\
\hline Area (mha) & $1953-54$ & 1.41 & $2006-07$ & 361.04 \\
\hline Production (mt) & $1953-54$ & 53.85 & $2011-12$ & 71.66 \\
\hline Productivity (t/ha) & $1952-53$ & 35.80 & $2011-12$ & \\
\hline
\end{tabular}

Table 3, clearly shows that lowest production during 1953-54 (53.85 mt) and highest production during $2011-12$ (361.04 mt) were obtained with six times increased production. In productivity, lowest (35.8 t/ha) and highest (71.66 t/ha) were recorded in 1952 - 53 and 2011-12 years, respectively. So productivity was doubled during last six decades. It is also clear that production was more led by area rather than productivity. In order to meet the growing demand of sugar and energy by 2050 in India, around $630 \mathrm{mt}$ of sugarcane with a recovery of $11.5 \%$ would be required of the total sugarcane produced, $70 \%$ would be crushed for white sugar, $20 \%$ for gur and khandsari and remaining $10 \%$ for seed and other purposes. According to estimates of the National Commission on Agriculture (NCA 1976) and by various agencies, the population of the country is expected to be 1.65 billion by 2050 .

\section{Sugarcane scenario in states:-}

Among the states in India, Uttar Pradesh leads with 21.60 lakh ha, followed by Maharashtra (9.878 lakh ha), Karnataka (4.0 lakh ha), Tamil Nadu (2.63 lakh ha). Production wise, U.P. leads with 133.20 mt followed by Maharashtra (75.09 mt), Karnataka (34.20mt), Tamil Nadu (27.62 mt), Bihar (14.24 mt). Yield wise west Bengal leads with (115.0 t/ha) followed by Tamil Nadu (105 t /ha), Karnataka (85.5 t/ha) and Andhra Pradesh (79.4 t/ha ).

Table 4:- Top five states in sugarcane area, production and yield in 2015 -16

\begin{tabular}{|c|c|c|c|c|c|c|}
\hline Rank & \multicolumn{2}{|c|}{ Area wise } & Production wise & \multicolumn{2}{c|}{ Yield wise } \\
\hline & State & Area (Lakh ha) & State & (mt) & State & (t/ha) \\
\hline 1 & Uttar Pradesh & 21.60 & Uttar Pradesh & 133.20 & Uttar Pradesh & 115.0 \\
\hline 2 & Maharashtra & 9.87 & Maharashtra & 75.09 & Maharashtra & 105.0 \\
\hline 3 & Karnataka & 4.00 & Karnataka & 34.20 & Karnataka & 91.50 \\
\hline 4 & Tamil Nadu & 2.63 & Tamil Nadu & 27.62 & Tamil Nadu & 85.50 \\
\hline 5 & Bihar & 2.58 & Bihar & 14.24 & Bihar & 79.40 \\
\hline \multicolumn{7}{|c|}{ Sources: Cooperative Sugar (2016) } \\
\hline
\end{tabular}




\section{Prospects and Hope:-}

Sugarcane being a long duration and bio mass - accumulating crop removes substantial amount of plant nutrients from the soil. Sugarcane crop of $100 \mathrm{t} / \mathrm{ha}$ exhausts $250 \mathrm{~kg} \mathrm{~N}, 55 \mathrm{~kg} \mathrm{P}$ and $275 \mathrm{~kg} \mathrm{~K}$ besides $3.5 \mathrm{~kg} \mathrm{Fe}, 1.2 \mathrm{~kg} \mathrm{Mn}$, $0.6 \mathrm{Kg} \mathrm{Zn}, 0.2 \mathrm{~kg} \mathrm{Cu}$ and $30 \mathrm{~kg} \mathrm{~S}$. However, sugarcane per se adds biomass in the soil including root biomass, stubbles and cane trashes.

Since, nutrients absorbed by cane plants from soil do not form the constituents of its marketable commercial product 'sugar', there is good opportunity of organic recycling in this crop. The microbial population in the sugarcane rhizosphere ranges from $10^{5}$ to $10^{6}$ counts $\mathrm{g}^{-1}$ root tissue.

Andrews and Kassam (1976) have analysed the prospects of intercropping and stated that world food supply through intercropping in developing countries must be seen in prospective, i.e., it is the only one element that fights against poverty.The researches on intercropping have confirmed that small farmers in developing countries like India have been doing and generally provides yield advantage as compared to sole cropping (Willey 1979). Numerous workers (Webster and Wilson 1966; Walters, 1971; Enyi, 1973) have stated that the more complete cover provided by intercropping reduces weed growth by competition. This results in the reduction in labour requirement for weeding. Moody (1976) observed that the growing of intercrops in close proximity to one another results in greater competition against weed and thus reduces the need for weeding. Attempts have been made to change the geometry of planting in favour of growing inter crops. The profits in inter cropping with different intercrops have ranged from 12 to 34\% (Lakshmikanthan 1983). There is tremendous scope of increasing area under pulses through intercropping in sugarcane under Indian tropics and subtropics.

Table 5:- Effect of pulses as intercrop with sugarcane on system productivity (Source: Sharma et., al. 1992).

\begin{tabular}{|l|l|l|l|}
\hline Cropping system & $\begin{array}{l}\text { Cane yield } \\
(\mathbf{t} / \mathbf{h a})\end{array}$ & $\begin{array}{l}\text { Inter crop yield } \\
(\mathbf{q} / \mathbf{h a})\end{array}$ & $\begin{array}{l}\text { Sugarcane equivalent yield } \\
(\mathbf{t} / \mathbf{h a})\end{array}$ \\
\hline Sugarcane sole & 81.00 & - & 81.00 \\
\hline Sugarcane + Field pea & 80.34 & 6.20 & 92.09 \\
\hline Sugarcane + Rajma & 78.14 & 7.20 & 99.85 \\
\hline Sugarcane + Chickpea & 77.58 & 11.40 & 96.11 \\
\hline
\end{tabular}

The compatibility of pulses as intercrop in sugarcane for enhancing system productivity has also been documented (Table 5). The compatibility of intercrops varies with the row arrangements (Yadav et al, 1987) and genotypes selected as intercrop in the system (Menhi Lal et. al; 2000).

\section{Effect of system on cane juice quality parameters:-}

As regards sucrose content in cane juice, the different intercrops had no significant effect on juice quality parameters. These results are in line with those reported by Rathi and Singh (1979), Nazir et al; (198), Shukla and Pandey (1999) and Li et al; (2011).

\section{Conclusions:-}

Pulses have very good opportunity to find place in different agro- ecosystems. Since last six decades in India, enhancement in productivity of most of the field crops has been obtained but much success could not be achieved in increasing area and productivity of pulse crops. Significant increment in area and productivity of pulses crops is possible by intercropping of these crops with sugarcane. There is great scope of increasing area under pulses crops through crop diversification besides improving their productivity.

\section{References:-}

1. Andrews, D.J., and A.N. Kassam. 1976. The importance of multiple cropping in increasing world food supplies. In multiple cropping, ed. R.K. Papendic, P.A. Sanche and G.B. Triplett, 1-10. Madison: American Society of Agronomy.

2. Blume, H (1985): Geography of sugarcane, Verlog. Dr. Albert Baten, Berlin, Germany.Cooperative Sugar. 2016. Statewise area, production and productivity of sugarcane in India. Cooperative Sugar 47: 44 -46

3. Enyi, B.A.C. 1973. Effect of plant population on growth and yield of soybeans. Journal of Agri 1. Sciences. 18: 131.138. 
4. Garside, A.L., and M.J. Bell. 1999. The potential for legumes in sugarcane cropping system in Australia Proceedings ISSCT, New Delhi 23: 100-106.

5. Hagelberg and Harris, 1976. Pluralism and uncertainty in the world sugar economy, Food policy: $271-285$.

6. Laksmikantha, M. 1983. Technology of sugarcane growing. New delhi. Oxford and IBH Publication.

7. Li, Z. X., J.W. Wang, W.T. Yang, Y.H. Shu, Q. Du, L.L. Liu, and L. Shu. 2011. Effects of reduced nitrogen application on the ytield, quality and economic benefit of sugarcane intercropped with soybean. Ying Yong Sheng Tai Xue, Bao, 22: 713 - 719 (Chinese).

8. Menhi Lal, A.K. Singh, M. Ali, R. Kumar, 2000. Agronomic evaluation of mung bean / urd bean genotypes intercropped with spring planted sugarcane. Extended summaries, National symposium on. Agronomy: challenges and strategies for the new millennium, Nov $15-18$, 2000, Junagarh. P. 380.

9. Moody, K. 1976. Weed control in multiple cropping. Paper presented for the Asian Rice farmers. 21 - 23 Sept., IRRI, Los Banos, Loguna, Philippines.

10. Moore, P. A \& Botha, F.C. 2014. Sugarcane physiology, biochemistry and functional biology. John Wiley \& Sons, Inc.

11. NCA, 1976. Report of the National Commission on Agriculture, 1976: Agrarian reforms, India. National Commission on Agriculture and Irrigation, 1976.

12. Nazir, M.S., I. A. Faqceer, G. Ali., R. Ahmad and T. Mahmood. 1988. Studies on planting geometry and intercropping in autumn sugarcane. Gomel University Journal of Research 8: 57 - 64.

13. Prakash, H.R., and G. Hunsigi, 1994. Effect of incorporation of intercropped legumes and nitrogen levels on yield for sustainable crop production. Uni. Of Agril. S ciences, Bangalore: pp - $44-45$.

14. Purthi, S. 1955. History of sugar industry in India, Reliance Publication House, New Delhi.

15. Rathi, K.S., and R.A. Singh, 1979. Companion cropping with autumn planted sugarcane. Indian Sugar Crop Journal, 69: $76-82$.

16. Sharma, R.K., K.S. Bangar, S.R., Sharma, H.B. Grewal, and O.P. Rathore. 1992. Comparative performance of intercropping pulses in sugarcane under south western M.P. Indian Journal o0f Agronomy 37: 95 -96.

17. Shukla, S.K. and M. B. Panday. 1999. Feasibility of inclusion of mustard genotypes in intercropping and sequential cropping system with sugarcane. Indian Jouranl of Agril. Sciences 69: 247 - 250.

18. Singh, N.P. 2015. Pulses in India: Current status and way formed. In : Proceeding of the regional consultation on the promotion of the pulses in Asia for multiple health benefits held at Bangkok, Thailand. 29 - 30 June, 2015: pp $67-72$

19. Walters, R.F. 1971. Shifting Cultivation in Latin America, FAO. Forest development, Paper17, p. 305, FAO, Rome, Webster, C.C. and P.N. Wilson, 1966. Agriculture in tropics, London, Longman, U.K.

20. Willey, R.W. 1979. Intercropping - its importance and its research needs. Competition and yield advantage. Field crop Abstracts, 31: 1010.

21. Yadav, R.L., S.R. Prasad, and K. Singh. 1987. Fertilizers requirement and row arrangement of pulses in sugarcane based cropping systems. Indian Journal of Agronomy. 32: 80-84. 